\title{
Effect of Larvicidal Extract N-Hexane Lime Leaves (Citrus hystrix) on Larva Instar III Mosquito (Culex quinquefasciatus)
}

\author{
Muhammad Hanif ${ }^{1}$, Nunuk Dyah Retno Lastuti ${ }^{1 *}$, and Rochmah Kurnijasanti ${ }^{2}$ \\ ${ }^{1}$ Department of Veterinary Parasitology, Faculty of Veterinary Medicine, Universitas Airlangga, Surabaya, East Java, Indonesia \\ ${ }^{2}$ Department of Basic Veterinary Medicine, Faculty of Veterinary Medicine, Universitas Airlangga, Surabaya, East Java, Indonesia \\ *Corresponding Author: Nunuk Dyah Retno Lastuti, Department of Veterinary Parasitology, Faculty of Veterinary Medicine, Universitas Airlangga, \\ Campus C UNAIR J1. Dr. Ir. H Soekarno, Surabaya, East Java, Indonesia 60115 \\ Corresponding author's E-mail: nunukdyah53@gmail.com; (DORCiD: 0000-0003-0176-1322
}

\begin{abstract}
Culex quinquefasciatus mosquitoes are a vector of transmission of several types of diseases, such as filariasis, Japanese encephalitis, and dirofilariasis. Larval control is the key strategy of disease control programs caused by vectors around the world because it can prevent larvae to enter the adult stage. Control of mosquito larvae that are often used is chemically controlled. Citrus hystrix is a natural plant and contains chemical compounds that have biological activity, such as flavonoids, carotenoids, and limonoids. The present study aimed to determine the effect of citrus leaf extract (Citrus hystrix) on the mortality of the larva Culex quinquefasciatus. The method used in the current study was a laboratory experimental study method with the experimental design using a completely randomized design. The research plot carried out was the rearing larvae of Culex quinquefasciatus, the manufacture of citrus leaf extract, the manufacture of larvicidal material, and the observation phase after treatment. Extract $\mathrm{N}$ hexane omplet name hystrix leaf has high toxicity because it contains essential oils, flavonoids, alkaloids, terpenoids, saponins, and Limonoids. The Optimal concentration of N-hexane extracts of citrus leaves that lead to larval mortality of Culex quinquefasciatus in vitro amounted to $93.33 \%$ on 4 hours of observation with a concentration of $4000 \mathrm{ppm}$. Extract $\mathrm{N}$-hexane lime leaf has a larvicidal effect on the larva Culex quinquefasciatus in vitro.
\end{abstract}

Keywords: Citrus hystrix, Culex quiquefasciatus, Extract, Mosquitoes, Larvicide

\section{INTRODUCTION}

Indonesia is a tropical country that has optimal humidity and temperature so as to support insect survival. Mosquitoes are the type of insects that coexist with humans but can harm humans because of their role as destructive organisms and disease vectors (vector-borne diseases; Sumantri and Satar, 2015).

Culex $(C x$.) quinquefasciatus mosquitoes are the vector of transmission of several types of diseases such as filariasis, Japanese encephalitis, and dirofilariasis (Hadi and Koesharto, 2006). Filariasis is an infectious disease caused by microfilarial worms. This disease can cause disability, psychosocial, and decreased patients' productivity. The number of filariasis cases in Indonesia increases annually. Japanese Encephalitis (JE) is a viral disease that causes encephalitis and is a problem of public health in Asia including in Indonesia. Mosquito control can be done at the larvae stage, but in the adult stage that mosquitoes can fly they can transmit the disease widely (Aradilla, 2009). The control of larvae is the key strategy of vector-borne disease control programs caused by vectors around the world because it can prevent larvae to become adults. The larvae stadium has the longest lifespan of about 10-15 days so that the exposure is also longer, adult stage or adult mosquitoes can also fly so that it can spread the disease widely. The use of insecticide as larvacide can be the most commonly used way for people to control the growth of the vector (Manimegalai and Sukanya, 2014). Control of mosquito larva that has been often used is chemical control, namely by using synthetic chemicals. It can suppress vector populations rapidly. However, control in this way when done repeatedly is less effective because it can cause resistance to larvae, death for animal predatory predators and environmental pollution (Yasmin and Fitri, 2013). Biolarvasida of a plant (vegetable) is considered quite potential replacing synthetic insecticide. Plant insecticides are generally more selective than chemical insecticides because they are directly targeted at the target insect species, but also do not pollute the environment because it is easily degraded by nature and its use is quite safe (Aktar et al., 2009). More than 2400 plant types that belong to 255 families are reported to contain pesticide ingredients. Basil, germanium, 
and zodia belong to a group of mosquito repellent plants due to their distinctive aroma. The plant contains compounds, such as methyl eugenol and some microelements, such as Linalool, Terpincol, Eugenol, Sincol, and Geraniol. In addition, there are other types of mosquito repellent including lavender, zodia, rosemary, fragrant lemongrass, and citrus kaffir lime (Kardinan, 2005). C. hystrix is a plant that is found easily by people. Plants derived from this genus of Citrus have chemical compounds that have biological activities, such as flavonoids, carotenoids, and Limonoids (Nurhaifah and Sukesi, 2015). Limonoid compounds are the teranoriterpen found in the leaves of Citrus lime which is potentially antifeedant to insects, growth regulator, and toxic substances in rice lice, larvacide, antimicrobial, insect repellent, and reproductive inhibitors $(\mathrm{Li}, 2001)$. The limonoid compound is an analog of juvenile hormones on insects that serve as a regulator of the growth of larval cuticles (Tunaz and Uygun, 2004). Saponin is also able to become biolarvasida. Saponin compounds in extracts that are eaten by the larvae of $C x$. quinquefasciatus may irritate the digestive tract of $C x$. Quinquefasciatus, and damage the cell membrane of the larva. Limonoid, which is an essential oil in orange, can lead to the loss of coordination of the nerve organ of the larva Cx. Quinquefasciatus (Pelah et al., 2002). In addition, limonoid has the ability to inhibit the formation of cancer cells, reducing the formation of low-density lipoproteins (LDL) as well as being able to suppress the appetite from insects (Murthy et al., 2021). Therefore, this research is done to find out the benefits of citrus leaves that are thought to have effects on larvae of $C x$. quinquefasciatus.

\section{MATERIALS AND METHODS}

The research was conducted in the entomology laboratory of The Institute of Tropical Disease (ITD), Airlangga University, and the Department of Medicine of Veterinary Faculty of Universitas Airlangga, Surabaya, Indonesia. The material used consists of 420 larvae instar III $C x$. quinquefasciatus obtained from the laboratory of ITD. Each treatment group used a sample of 20 larvae.

The current study utilized experimental research methods of laboratories with the experimental design using a completely randomized design using simple random sampling. The study was conducted in several phases, namely the rearing phase of the larva of $C x$. quinquefasciatus, the manufacturing stage of citrus leaf extract of $C$. hystrix, the manufacturing stage of larvacidal material, and the observation phase after treatment. In rearing the larvae of $C x$. quinquefasciatus, selection was based on the body length (5-6 millimeters, determined by a compound microscope with calibrated eyepiece graticule) and the day after the eggs hatch (four to six days). There was a triangular thickening consisting of many comb-shaped scales, had complete its morphological structure, and clearly, the body could be divided into a part of the head, chest, and abdomen. Prior to the study, the larvae were restored in advance in order to prove that the administration proved optimal. Subsequently, 420 larvae of instar III of Cx. quinquefasciatus were divided into seven treatment groups, namely the control group (+) consisting of Temephos $1 \mathrm{ppm}+$ aquadest AD $100 \mathrm{ml}$ solution, the control group (-) consisting of a solution of aquadest $100 \mathrm{ml}$, treatment 1 entailing $25 \mathrm{mg}$ of citrus leaf extract of kaffir lime + aquadest $\mathrm{AD} 100 \mathrm{ml}$, treatment 2 consisting of $50 \mathrm{mg}$ of kaffir lime citrus leaf extract + aquadest $\mathrm{AD} 100 \mathrm{ml}$, treatment 3 having $100 \mathrm{mg}$ Citrus leaf extract of kaffir lime + aquadest AD $100 \mathrm{ml}$, treatment 4 including $200 \mathrm{mg}$ citrus leaf extracts of kaffir lime + aquadest AD $100 \mathrm{ml}$, treatment 5 consisting of $400 \mathrm{mg}$ of citrus leaf extracts of kaffir lime + aquadest AD $100 \mathrm{ml}$. The larvacide extract of the kaffir lime citrus leaves was then poured into plastic cups. Then, into the plastic cups that have been contained treatment solution inserted larvae of 20 tails of each glass. Observations were performed every 4 hours for 24 hours to see the dead larvae.

The physical factors measured in the room used during the study included the $\mathrm{pH}$ of water, water temperature, and room temperature. Measured water $\mathrm{pH}$ ranges from 7.0 to 7.2. The condition is a neutral $\mathrm{pH}$ and qualifies for the life of larvae in water. The measured room temperature is $25^{\circ} \mathrm{C}$, which is the temperature suitable for larvae growth.

\section{RESULTS}

Result of soaking larvae Instar III of Cx. quinquefasciatus in various concentrations of treatment for 24 hours obtained the average value and standard deviation of the number of Instar larva III Cx. quinquefasciatus every 4 hours observation that can be seen in Table 1.

Based on Table 1 above, it can be noted that there is a significant difference in each treatment of the percentage of mortality of Instar-III Larva $(\mathrm{p} \leq 0.05)$. However, the results of a comparison of immersion treatment in solution Temephos with extracts N-hexane citrus leaves of 4000 ppm concentrations do not show a noticeable difference. It is different from the immersion comparison of Temephos solution $1 \mathrm{ppm}$ with the $\mathrm{N}$-hexane extracts of citrus leaves with the concentrations of 2000, 1000,500, and $250 \mathrm{ppm}$ which show noticeable different results. Extract N-hexane citrus leaves of $4000 \mathrm{ppm}$ concentrations at a 4-hour observation have shown an average death of as much as 19 tails so that it can be known that the value $\left(\mathrm{LC}_{90}\right)$ of extract n-hexane lime leaf is $4000 \mathrm{ppm}$. More details can be seen in Figure 1 .

Based on Figure 1 of the comparative mortality ratio of Larva $C x$. quinquefasciatus on the observation every 4 hours for 24 hours obtained the result that the relationship between the concentration of N-hexane extracts of citrus 
leaves with larvae instar-larva III $C x$. quinquefasciatus have a positive direction, meaning the higher concentrations of citrus leaf extract kaffir lime, the higher the power of the larva of mosquitoes $C x$. quinquefasciatus. The increased immersion time at the concentrations of P1, P2, P3, and P4 showed an increase in the number of deaths each time of observation, it showed the time of immersion of N-Hexsan extract material affecting the death process of the mosquito larva $C x$. quinquefasciatus. In negative control does not encounter the death of larvae it indicates there is no reaction of the use of aqueous solutions.

The results in the experiment indicated a significant difference in each treatment. This means that the death of the larvae of instar III Cx. quinquefasciatus was due to the immersion of the larvae in the kaffir lime citrus leaf extract. Insignificant differences in the positive control and the highest concentration of citrus leaf extract kaffir lime resulted from the equation of the effectiveness of citrus leaf extract in the killing of larvae.

Table 1. The results of soaking larvae every four hours

\begin{tabular}{lcccccc}
\hline \multicolumn{1}{r}{$\begin{array}{l}\text { Mortality (\%) } \\
\text { Error: Bookmark } \\
\text { not defined. }\end{array}$} & \multicolumn{5}{c}{ Average \pm standard deviation } \\
\cline { 2 - 7 } Groups & $\mathbf{4}$ hours & $\mathbf{8}$ hours & 12 hours & $\mathbf{1 6}$ hours & $\mathbf{2 0}$ hours & $\mathbf{2 4}$ hours \\
\hline K (+) & $88.33 \pm 2.88$ & $100 \pm 0$ & $100 \pm 0$ & $100 \pm 0$ & $100 \pm 0$ & $100 \pm 0$ \\
K (-) & $0 \pm 0$ & $0 \pm 0$ & $0 \pm 0$ & $0 \pm 0$ & $0 \pm 0$ & $0 \pm 0$ \\
P1 & $11 \pm 5.77$ & $21.66 \pm 5.77$ & $25 \pm 5$ & $30 \pm 5$ & $38.33 \pm 7.63$ & $41.66 \pm 7.63$ \\
P2 & $15 \pm 5$ & $28.33 \pm 7.63$ & $36.66 \pm 5.77$ & $38.33 \pm 7.63$ & $48.33 \pm 10.40$ & $51.66 \pm 7.63$ \\
P3 & $30 \pm 13.22$ & $45 \pm 13.22$ & $56.66 \pm 14.43$ & $66.66 \pm 10.40$ & $76.66 \pm 5.77$ & $78.33 \pm 7.63$ \\
P4 & $55 \pm 5$ & $63.33 \pm 7.63$ & $68.33 \pm 10.40$ & $73.33 \pm 7.63$ & $80 \pm 10$ & $91.66 \pm 10.4$ \\
P5 & $93.33 \pm 2.88$ & $100 \pm 0$ & $100 \pm 0$ & $100 \pm 0$ & $100 \pm 0$ & $100 \pm 0$ \\
\hline
\end{tabular}

K+: Temephos, K-: Aquadest, P1: 250 ppm, P2: 500 ppm, P3: 1000 ppm, P4: 2000 PPM, and P5: 4000 ppm

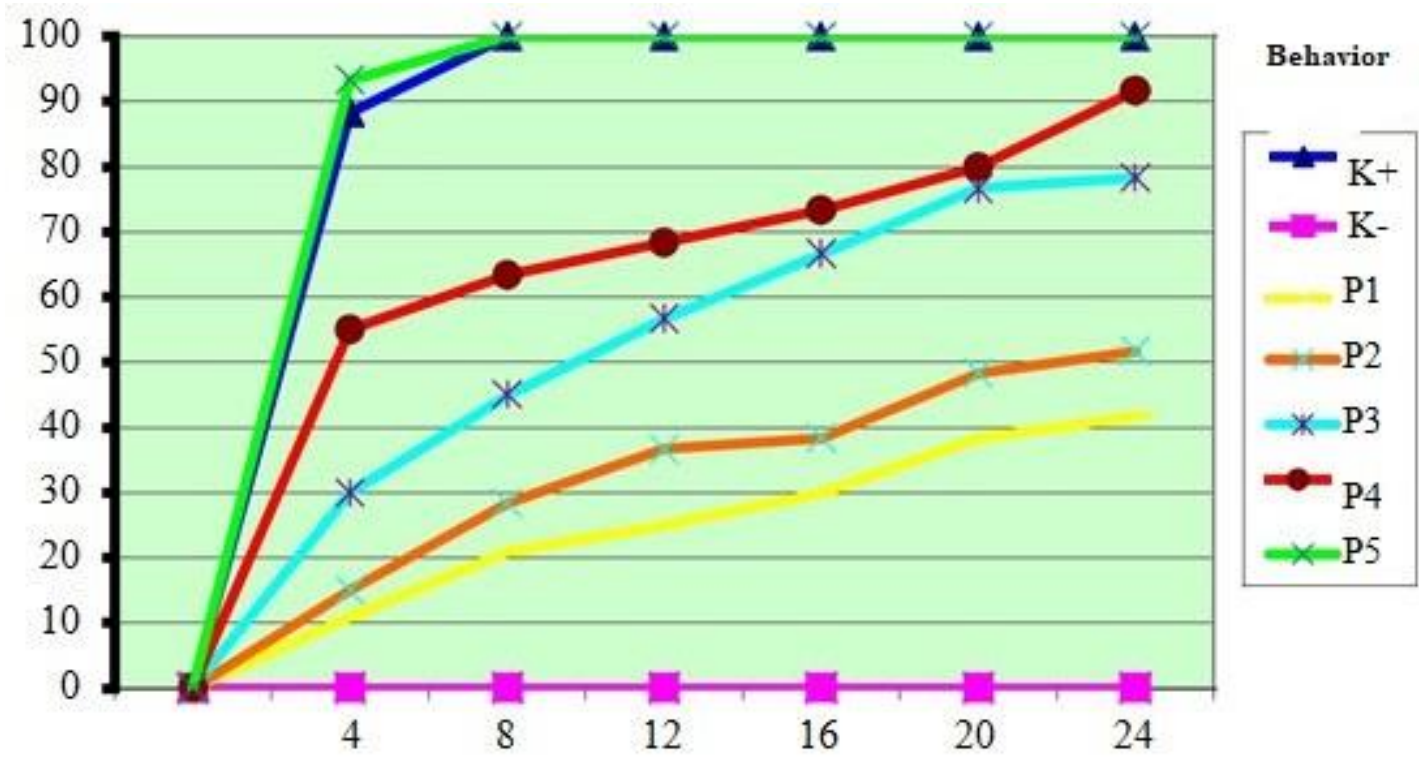

Figure 1. Comparative mortality of Larva $C x$. quinquefasciatus on observation every 4 hours in a day, $\mathrm{K}+$ : Temephos, $\mathrm{K}-$ : Aquadest, P1: 250 ppm, P2: 500 ppm, P3: 1000 ppm, P4: 2000 PPM, and P5: 4000 ppm

\section{DISCUSSION}

The results of soaking larvae on the negative control $(\mathrm{k}-)$ of the larvae mortality rates were $0 \%$ for every four hours (Table 1). This means that the larvae were still alive and the addition of aquadest in control treatment did not show any effect on the mortality of larvae. In positive control $(\mathrm{k}+)$, the death of Larva instar III Cx. quinquefasciatus resulted from the administration of Temephos $1 \mathrm{ppm}$ solution. Temephos is an organophosphate larvicide used to treat water infested with disease-carrying insects. This larvide has a residual power of approximately one month in the water shelter. As with other organophosphates, temephos affects the central nervous system through inhibition of cholinesterase. In larvae, this results in death before reaching the adult stage. The function of the enzyme cholinesterase is to hydrolyze acetylcholine into choline and sour vinegar (acetic acid) so that if the enzyme is inhibited then hydrolyze acetylcholine does not occur so that the muscles will remain contracted for a long time and will occur continuously, and the insect will eventually die (Nugroho, 2011). So as with other organophosphate compounds, Temephos acts as an anticholinesterase (Nugroho, 
2011). Chemical compounds in plants that are potentially biolarvicides, are flavonoids, saponins, tannins, alkaloids, and essential oils (Kristanti et al., 2008). The C. hystrix leaf extract has high toxicity of lime leaves (Citrus aurantifolia), lime leaves (c. amblycarapa), and Balinese citrus leaves (c. maxima; Adrianto et al., 2014). The kaffir lime leaves contain essential oils, flavonoids, alkaloids, terpenoids, saponins, and limonoids (Adrianto et al., 2014).

Limonoid compounds are an important natural active component consisting of oxidized triterpenoid components (Khalil et al., 2003). Limonoid causes a bitter taste in orange and has the most potent larvacide effects. The larva cannot be transformed into a pupa because the title of the juvenile hormone in the larvae is not reduced but increases. To be a pupa, larva needed lower amounts of Juvenile hormones. Although the larvae make the skin change to instar IV, the larva will not be able to metamorphosis into the pupa and eventually die (Prijadi et al., 2014). Limonoida can enter into the body of the mosquito larva (Aedes aegypti) as a stomach poison. Limonoida goes into digestion through the concentration of the eaten extract concentrations. Insecticides will enter into the digestive organs of insects and are absorbed by the intestinal wall then circulate with blood that will interfere with the metabolism of mosquitoes so that it will lack energy for his life activities that will result in mosquitoes it is seizure and eventually dies (Baskar et al., 2020).

Another substance contained in the leaves of lime that can interfere with insects in digesting food is saponin. Saponin can lower the surface tension of the mucous membrane of the digestive tract larvae. The interaction of the saponin molecules with a layer of larval cuticle will result in damage to the cuticle (Chapagain and Wiesman, 2005). Saponins can also lower the enzyme activity of proteases in the gastrointestinal tract as well as interfere with food absorption (Afidah et al., 2014).

This alkaloid content acts as a stomach poison and contact poison. The alkaloid is a grain of salt so that it can degrade the cell membrane of the digestive tract to enter into and damage cells and can also interfere with the nervous system work of larvae by inhibiting the enzyme work of acetylcholinesterases. Where this enzyme cannot execute its duties in the body mainly forward the delivery of orders to the digestive tract larvae (midgut) so movement cannot be controlled. The occurrence of discoloration in the body of larvae becomes more transparent and the movement of larvae slows down when the touch is stimulated and always bends the body also caused by alkaloid compounds (Ahdiyah and Purwani, 2015).

Tannins are polyphenol compounds that can form complex compounds with proteins. Tannins cannot be digested in the stomach and have a connective power with proteins, carbohydrates, vitamins, and minerals. Tannins can interfere with insects in digesting food because tannins will bind to proteins in the digestive system that required insects for growth so that the digestive process is estimated that become disturbed to the larva Cx. Quinqufasciatus (Yunita et al., 2009).

The death of Larva instar III $C x$. quinquefasciatus not only was resulted from the compounds of limonoid but this can also be caused by various ingredients contained in the extract $\mathrm{N}$-hexane lime leaves such as materials that have been mentioned above which can affect the death of larva $C x$. Quinqufasciatus. Therefore, The higher the concentration, the higher the content of the active ingredient contained in the extract of $\mathrm{N}$-hexane lime leaves, which can cause a decrease in digestive activity, causing seizures and disrupt the nervous system and suppress the rate of growth of larvae (Minarni et al., 2013). The content of essential oils that are the secondary metabolite of extracts that are dissolved with aquadest will cause an oil layer to be formed due to differences in polarity. This coating will cover the water surface and siphon. The presence of oil will prevent larvae from taking oxygen, even the coating of oil will stick to the siphon will prevent the diffusion of oxygen towards the tissues, so that oxygen transport is interrupted. The nature of this essential oil can be respiratory poison (Hedayat, 2008).

After soaking the extract of N-hexane citrus leaf, the following kaffir lime signs were observed. In the first 15 minutes, the larvae $C x$. quinquefasciatus showed a rapidly rising movement, convulsive movements, such as forming the $\mathrm{U}$, weakened body movements, at 2 hours of observation time at concentrations of $4000 \mathrm{ppm}$ and 2000 ppm has begun to show the situation where the larvae are unable to move, stiff, and subsequently die. The results of soaking larvae every 4 hours were observed. Larvacida contact poison can kill enough larva when exposed to external body parts. Then larvae show the sign of ascending movement rapidly (telescopic movement).

The results of the research on the concentration of the extract of N-hexane lime leaves at all treatments except the negative control (k-) were the death of larvae. The mortality rate of larvae at a concentration of 4000 ppm was $93.33 \%$. This concentration is the best concentration of $\mathrm{N}$-hexane extracts of citrus leaves as larvacide. The difference between the numbers of larvae deaths is caused by the concentration of each treatment. This indicates that the higher the concentration and duration of observations of N-hexane citrus leaves of the purut, the higher the active content and the larvasidal power to kill the larva of quinquefasciutus mosquitoes.

When compared, concentration 4000 ppm extract N-hexane citrus leaves are equally effective with a solution Temephos 1 ppm in killing the larva instar III $C x$. quinquefasciatus is the same as indicating the death of $100 \%$. But for the efficiency of the solution temephos is higher in killing the larvae Cx. Quinqufasciatus then extract N-hexane citrus leaves of kaffir lime with a concentration of $4000 \mathrm{ppm}$ because it only takes $1 \mathrm{ppm}(\mathrm{mg} / \mathrm{l})$ of Temephos solution, compared to 4000 ppm (mg/l) extract N-hexane lime leaves to kill 100\% larvae for 8 hours in a 24-hour time. 


\section{CONCLUSIONS}

The findings of this study have confirmed that extracts of N-hexane lime leaves contain active substances that can be larvicidal. Therefore, the results larvacides are considered good when the test material shows the value of mortality between $90-100 \%$ of test larvae. In conclusion extract of $\mathrm{N}$-hexane kaffir lime orange leaves have a larvicidal effect on the larva $C x$. quinquefasciatus in vitro. The optimal concentration of $\mathrm{N}$-hexane extracts of citrus leaves that cause the larval mortality of $C x$. quinquefasciatus in vitro amounted to $93.33 \%$ on 4 hours of observation with a concentration of 4000 ppm.

\section{DECLARATIONS}

\section{Competing interests}

Authors declare no competing interests.

\section{Authors' contribution}

The authors have participated in this study equally.

\section{Ethical consideration}

Ethical issues (Including plagiarism, consent to publish, misconduct, data fabrication and/or falsification, double publication and/or submission, and redundancy) have been checked by the authors.

\section{REFERENCES}

Adrianto H, Yotopranoto S and Hamidah (2014). Efektivitas ekstrak daun jeruk purut (Citrus hystrix), jeruk limau (Citrus amblycarpa), dan jeruk Bali (Citrus maxima) terhadap larva Aedes aegypti. Aspirator, 6(1): 1-6. DOI: https://www.doi.org/10.22435/ASPIRATOR.V6I1.3516.1-6

Afidah R, Yuliani and Haryono T (2014). Pengaruh kombinasi filtrat umbi gadung, daun sirsak, dan herba anting-anting terhadap mortalitas larva ordo lepidoptera. LenteraBio, 3(1): 45-49. available at: http://ejournal.unesa.ac.id/index.php/lenterabio

Ahdiyah I and Purwani KI (2015). Pengaruh ekstrak daun mangkokan (Nothopanax scutellarium) sebagai larvasida nyamuk Culex sp. Jurnal sains dan Seni ITS, 4(2): 32-36. DOI: https://www.doi.org/10.12962/j23373520.v4i2.10804

Aktar MW, Sengupta D, and Chowdhury A (2009). Impact of pesticides use in agriculture: their benefits and hazards. Interdiscip Toxicol, 2(1): 1-12. DOI: https://www.doi.org/10.2478/v10102-009-0001-7

Aradilla AS (2009). uji efektivitas larvasida ekstrak ethanol daun mimba (Azadirachta indica) tehadap larva Aedes aegypti. Medical faculty, pp. 1-47. DOI: https://www.doi.org/10.1002/bjs.1800560511

Baskar K, Chinnasamy R, Pandy K, Venkatesan M, Sebastian PJ, Subban M, Thomas A, Kweka EJ, and Devarajan N (2020). Larvicidal and histopathology effect of endophytic fungal extracts of Aspergillus tamarii against Aedes aegypti and Culex quinquefasciatus. Heliyon, 6(10): 1-11. DOI: https://www.doi.org/10.1016/j.heliyon.2020.e05331

Chapagain B and Wiesman Z (2005). Larvicidal effects of aqueous extracts of Balanites aegyptiaca (desert date) against the larvae of Culex pipiens mosquitoes. African journal of Biotechnology, 4(11): 1351-1354. Available at: https://www.ajol.info/index.php/ajb/article/view/71379/60329

Hadi UK and Koesharto FX (2006). Nyamuk dalam buku hama permukiman Indonesia, pengenalan, biologi dan pengendalian, UKPHP FKH IPB, Bogor.

Hedayat KM (2008). Essential oil diffusion for the treatment of persistent oxygen dependence in a three-year-old child with restrictive lung disease with respiratory syncytial virus pneumonia. Explore, 4(4): 264-276. DOI: https://www.doi.org/10.1016/j.explore.2008.04.005

Kardinan A (2005). Tanaman pengusir dan pembasmi nyamuk. Jakarta: Agro Media Pustaka, pp. 2-5. Available at: https://agromedia.net/katalog/tanaman-pengusir-pembasmi-nyamuk

Khalil AT, Maatooq GT and El Sayed KA (2003). Limonoids from Citrus reticulata. Zeitschrift für Naturforschung C. Verlag der Zeitschrift für Naturforschung, 58(3-4): 165-170. Available at: https://pubmed.ncbi.nlm.nih.gov/12710721/

Kristanti et al (2008) Buku Ajar Fitokimia, Surabaya: Jurusan Kimia Laboratorium Kimia Organik FMIPA Universitas Airlangga, pp. 49-149. Available at: https://onesearch.id/Record/IOS1.INLIS000000000294108

Li J (2001). Brief Introduction to Citrus Limonoids, TAMU-College Station, TAMUK-Citrus Center. Available at: https://aggie-horticulture.tamu.edu/syllabi/422/ppt/LI.ppt 
Manimegalai K and Sukanya S (2014). Biology of the filarial vector, Culex quinquefasciatus (Diptera:Culicidae). International Journal of Current Microbiology and Applied Sciences. 3(4): 718-724. Available at: https://www.ijcmas.com/vol-3-4/K.Manimegalai\%20and\%20S.Sukanya.pdf

Minarni E, Armansyah T and Hanafiah M (2013). Daya larvasida ekstrak etil asetat daun kemuning (Murraya paniculata (L) jack) terhadap larva nyamuk Aedes aegypti. Jurnal Medika Veterinaria, 7(1): 27-29. Available at: http://jurnal.unsyiah.ac.id/JMV/article/view/2915

Murthy KNC, Jayaprakasha GK, Safe S, and Patil BS (2021). Citrus limonoids induce apoptosis and inhibit the proliferation of pancreatic cancer cells. Food and Function, 12(3): 1111-1120. DOI: https://www.doi.org/10.1039/d0fo02740e

Nugroho AD (2011). Kematian Larva Aedes aegypti Setelah Pemberian Abate Di bandingkan Dengan Pemberian Serbuk Serai. Jurnal Kesehatan Masyarakat, 7(1): 91-96. Available at: https://journal.unnes.ac.id/nju/index.php/kemas/article/view/2802/2858

Nurhaifah D and Sukesi TW (2015). Efektivitas Air Perasan Kulit Jeruk Manis sebagai Larvasida Nyamuk Aedes aegypti. Kesmas: National Public Health Journal, 9(3): 156-207. DOI: https://www.doi.org/10.21109/kesmas.v9i3.566

Pelah D, Abramovich Z, Markus A, and Wiesman Z (2002). The use of commercial saponin from Quillaja saponaria bark as a natural larvicidal agent against Aedes aegypti and Culex pipiens. Journal of Ethnopharmacology. 81(3): 407-9. DOI: https://www.doi.org/10.1016/s0378-8741(02)00138-1

Prijadi DK, Wahongan GJP, and Bernadus JBB (2014). Effectiveness Test Citrus Leaf Extract (Citrus aurantifolia) on Inhibits the Growth of Aedes spp Larvae. Jurnal e-Biomedik, 2(1): 1-7. Available at: https://media.neliti.com/media/publications/68248-ID-uji-efektifitas-ekstrak-daun-jeruk-nipis.pdf

Sumantri A and Satar YP (2015). Uji Efikasi Ekstrak Biji Srikaya (Annona squamosa L) Sebagai Bioininteksida Dalam Upaya Integrated Vector Management Terhadap Aedes aegypti. pp. 1-123. Available at: https://docplayer.info/58394667-Uji-efikasi-ekstrak-biji-srikaya-annona-squamosal-l-sebagai-bioinsektisida-dalamupaya-integrated-vector-management-terhadap-aedes-aegypti.html

Tunaz H, and Uygun N (2004). Insect growth regulators for insect. Turkish Journal of Agriculture and Forestry, 28(6): 377-387. Available at: https://journals.tubitak.gov.tr/agriculture/issues/tar-04-28-6/tar-28-6-1-0309-5.pdf

Yasmin Y and Fitri L (2013). Perubahan morfologi larva nyamuk akibat pemberian larvasida bakteri kitinolitik. Jurnal Entomologi Indonesia, 10(1): 18-23. DOI: https://www.doi.org/10.5994/jei.10.1.18

Yunita EA, Suparpti NH and Hidayat JW (2009). Pengaruh ekstrak daun teklan (Eupatorium riparium) terhadap mortalitas dan perkembangan larva Aedes aegypti. Department of Biology, MIPA UNDIP, 11(1): 11-17. Available at: https://core.ac.uk/download/pdf/11703242.pdf 